\title{
INFLUENCE OF NANODISPERSED COMPOSITIONS ON STRUCTURE FORMATION OF HIGH-STRENGTH ALUMINUM ALLOYS
}

\author{
Kalinina N.E. ${ }^{1}$, Hlushkova D.B. ${ }^{2}$, Voronkov A.I. ${ }^{2}$, Kalinin A.V. ${ }^{3}$, \\ Stepanuk A.I. ${ }^{2}$, Voronova E.M., ${ }^{2}$ Serzhenko I.O. ${ }^{4}$ \\ ${ }^{1}$ O. Honchar Dnipro National University, \\ ${ }^{2}$ Kharkiv National Automobile and Highway University, \\ ${ }^{3}$ State Higher Educational Institution Prydniprovska State Academy of \\ Civil Engineering and Architecture, \\ ${ }^{4}$ National Metallurgical Academy of Ukraine
}

\begin{abstract}
An analytical review of the state of the problem of aluminum alloys modification was performed. The absence of a unified approach to solving the problem has been established, which is associated with the complexity of the process of modifying multicomponent alloys. The aluminum alloys of the AL-Zn-Mg-Cu system were studied. As a modifier, a composition based on nanodispersed powders of titanium and boron with fractions of up to $100 \mathrm{~nm}$, obtained with plasma-chemical synthesis, is proposed. The structure, phase composition, and properties of the test samples were studied before and after modification with methods of optical microscopy, $X$-ray diffraction analysis, and $X$-ray spectral analysis. In the modified B95 and B96 alloys, grain refinement and structure stabilization were achieved. Determination of the crystal lattice parameters of the alloys showed an increase in the period of lattice of the modified samples by $1.02 \%$. The microhardness of $\alpha$-Al, the solid solution, was increased from 1080 to $1500 \mathrm{MPa}$. The phase composition of B95 and B96 alloys is represented with the intermetallic phases $\mathrm{CuAl}, \mathrm{MgZn}, \mathrm{Mg}_{2} \mathrm{Zn}_{3}, \mathrm{Mg}_{2} \mathrm{Si}, \mathrm{FeAl} \mathrm{l}_{3}, \mathrm{TiB}_{2}, \mathrm{TiAl}_{3}$, as well as phases of complex composition. The maximum grain refinement and increase in the mechanical properties of the alloys were achieved upon modification of $0.05 \%$ Ti and $0.005 \% \mathrm{~B}$, which is explained by the formation of dispersed strengthening intermetallic phases of complex composition in the center of the grains.
\end{abstract}

Key words: aluminum alloys, structure, phase composition, intermetallic phases, nanomodifier, titanium, boron.

\section{Introduction}

Currently, there are several aluminum alloys modification theories, but there is no consensus on solving this problem [1-3]. This is due, firstly, to the complexity of the modification process and its dependence on the melting and casting conditions and, secondly, to the influence of uncontrolled impurities and components, which can enhance or weaken the modifying effect. According to the nucleation theory, developed in [4-6] papers, the additive introduced as a modifier must satisfy the following requirements:

- it should have sufficient stability in the melt without changing the chemical composition;

- the melting temperature of the additive should be higher than the melting temperature of aluminum:

- structural and dimensional correspondence of the crystal lattices of the addition to the matrix melt is necessary;
- the formation of sufficiently strong adsorption bonds with atoms of the modified melt.

Apparently, the surface tension at the "melt solid particle" boundary, can serve as a criterion of the strength of interatomic bonds. The greater the surface tension value, the worse the particle is wetted by the liquid phase and the less likely it is to use the particle as a crystallization center. In $[4,5]$ papers on a large number of systems it was shown that the catalytic activity of the substrate during nucleation is determined by the chemical nature.

The role of modifiers is comes, on the one hand, to a decrease in surface tension at the crystal faces, which contributes to an increase in the rate of nucleation of crystallization centers, and on the other hand, to the formation on the surface of adsorption films that impede the diffusion of atoms of the crystallizing phase to the surface of the crystals and inhibit their growth. Slowing crystal growth leads to an increase in 
the number of crystallization centers and to a refinement of the structure. Adsorption theory does not explain the shift of the eutectic point and the formation of overmodified structures in aluminum alloys [6].

Application of the cluster model of the melt to the analysis of the modification process allowed the authors of $[7,8]$ papers to substantiate the solubility factor as one of the determining ones. Impurities soluble in clusters and changing their internal structure are classified as microalloying elements. Impurities soluble in the area of activated atoms are classified as second-type modifiers that change the crystallization process without changing the internal structure of the clusters. However, there is no clear distinction between modifiers and microalloying elements, since there are no substances soluble only in liquid state and absolutely insoluble in solid state.

Work objective: to stabilize the structure and the strengthening effect of the modification of multicomponent aluminum alloys with nanodispersed compositions.

\section{Influence of nanodispersed compositions on structure formation of high-strength aluminum alloys}

The material for study was high-strength aluminum alloys B95, B96 of the $\mathrm{Al}-\mathrm{Zn}-\mathrm{Mg}-\mathrm{Cu}$ system (Table 1).

Table 1 - The chemical composition of high-strength aluminum alloys

\begin{tabular}{|l|c|c|c|c|c|c|c|}
\hline Alloy & \multicolumn{7}{|c|}{ The content of elements, \% wt. } \\
\hline & Zn & $\mathrm{Mg}$ & $\mathrm{Cu}$ & $\mathrm{Mn}$ & $\mathrm{Cr}$ & $\mathrm{Fe}$ & $\mathrm{Si}$ \\
\hline B95 & 6,0 & 2,3 & 1,7 & 0,4 & 0,18 & $<0,5$ & $<0,5$ \\
\hline B96 & 8,5 & 2,6 & 2,3 & - & - & $<0,4$ & $<0,3$ \\
\hline
\end{tabular}

A modification technology has been developed consisting in introducing a weighed portion of the modifier $0.1 \mathrm{wt} . \%$ in the melt under the following temperature and time parameters: $\mathrm{t}$ $=720{ }^{\circ} \mathrm{C}$, modifier action time is $5 \ldots 7$ minutes. The modifier was nanodispersed powders of titanium and boron fractions up to $100 \mathrm{~nm}$. Xray microspectral analysis was performed on a JSM-66360JA multipurpose scanning microscope, with the JED 2200 energy-dispersive analysis system. The phase composition and crystal lattice periods of alloys before and after modification were determined using method of X-ray diffraction analysis on a DRON-2.0 diffractometer in $\mathrm{Cu}_{\alpha}$ radiation. Mechanical tests were performed on standardized equipment.
Mechanical tensile testing of the samples was performed in accordance with GOST 28840-90 on a TIRAtest testing machine. Impact strength tests were performed according to DSTU EN 10045-1:2006 under room temperature on a MK-30 pendulum impact testing machine.

The paper presents a methodology for the complex modification of aluminum melt, which can be explained as follows. If another insoluble additive is introduced into the melt with the main additive isomorphic to aluminum, then interval of melt metastability will decrease as a result. As shown in [7-9, 10] papers, titanium is the most effective refractory modifier element for aluminum. Boron was selected as the second titanium additive in the complex modification of aluminum alloys.

The following explanation can be given regarding enhancing the action of the complex modifier. Considering the triple state diagram of Al-Ti-B (Fig. 1) [11], we can conclude that titanium diboride $\mathrm{TiB} 2$ and titanium aluminide $\mathrm{TiAl}_{3}$ form a continuous series of solid solutions. Triple eutectic is formed in the system: $\mathrm{g}$ $+\mathrm{TiB}_{2}+\mathrm{TiAl}_{3}$. Introduction of boron expands the area of primary crystallization of $\mathrm{TiAl}_{3}$ as a result of a decrease in the solubility of titanium in liquid aluminum. The main modifier in this case is $\mathrm{a} \mathrm{TiB}_{2}$ particle, which has a structural correspondence with the matrix of alloys with a small difference in the parameters of the crystal lattices.

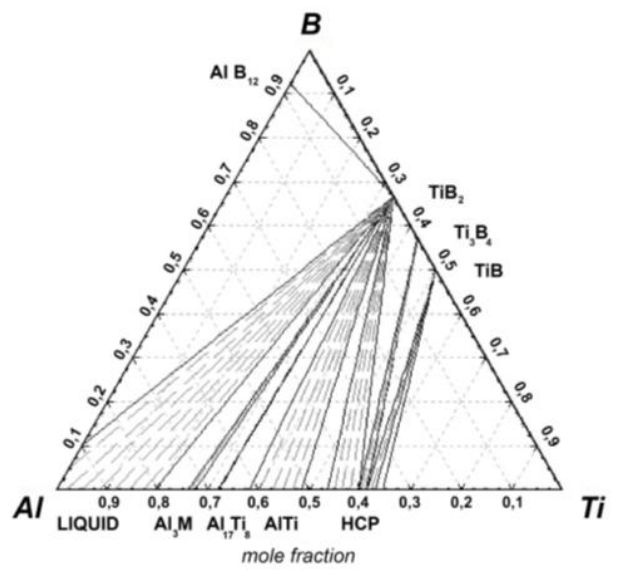

Figure 1. Ti-Al-B state diagram

Multicomponent aluminum alloys B95 and B96 contain $11 . .14 \%$ of alloying elements soluble in aluminum: zinc, copper, magnesium, manganese, chromium (Table 1). Alloying elements in quenched alloy are in solid solution. During aging process, solid solutions decompose with the production of dispersed inclusions of hardening phases (Fig. 2). 


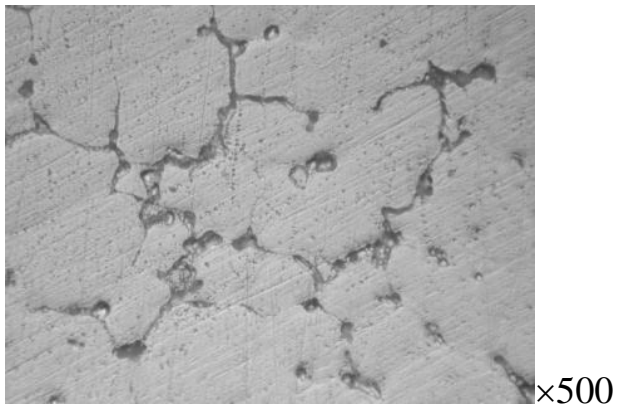

a

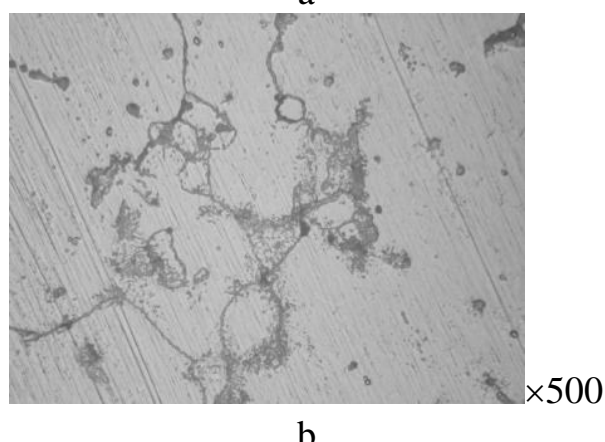

b

Figure 2. Microstructure of alloy B95 after quenching and aging: a - before modification; $b$ - after modification

The properties of the alloy depend on whether the alloying element is in a solid solution or in an intermediate phase. The location of elements and the degree of supersaturation can be judged by the size of the crystalline lattice of the solid solution.

An analysis of the characteristics of solid solutions in aluminum alloys shows [9, 10] that most alloying elements decrease the lattice period; the most effective is titanium. Magnesium, in turn, increases the period of the crystal lattice. Complex alloying can lead to the fact that the solid solution will be supersaturated and the lattice period does not change, i.e. the influence of different atoms on the lattice period is mutually compensated. According to X-ray diffraction analysis, the crystal lattice period of the B95 alloy in the initial state was 4.054 Á, and in the modified $(0.05 \% \mathrm{Ti}+0.005 \% \mathrm{~B})$ it was $4.055 \AA$. Thus, the increase in the lattice period was $1.02 \%$. At the same time, the microhardness of the matrix of modified alloys is increased.

The phase composition of the B95 alloy, which crystallized under equilibrium conditions, is represented by $\alpha-\mathrm{Al}$, a solid solution, as well as numerous intermetallic phases, both binary, $\mathrm{CuAl}_{2}, \mathrm{Mg}_{2} \mathrm{Zn}_{3}, \mathrm{Mg}_{2} \mathrm{Si}, \mathrm{FeAl}_{3}, \mathrm{TiAl}_{3}$ of the Laves type, and more complex phases. A large number of intermetallic compounds is formed due to the fact that aluminum is trivalent and has a high electronegative potential. Table 2 shows the identified intermetallic phases.

Table 2 - Intermetallic phases, hardening aluminum alloys

\begin{tabular}{|c|c|}
\hline Before modifying & After modification \\
\hline $\mathrm{FeAl}_{3}$ & $\mathrm{FeAl}_{3}$ \\
\hline $\mathrm{CuAl}_{2}$ & $\mathrm{Al}_{3} \mathrm{Ti}$ \\
\hline $\mathrm{MgZn}_{2}$ & $\mathrm{MgZn}_{2} \mathrm{MgZn}$ \\
\hline $\mathrm{Al}_{2} \mathrm{Cu}_{2} \mathrm{Fe}$ & $\mathrm{Al}_{2} \mathrm{Cu}_{2} \mathrm{Fe}$ \\
\hline $\mathrm{Mg}_{2} \mathrm{Si}$ & $\mathrm{Mg}_{2} \mathrm{Si}$ \\
\hline & $\mathrm{Mg}_{32}(\mathrm{AlCu})_{49}$ \\
$\mathrm{Mg}_{32}(\mathrm{AlCu})_{49}$ & $\mathrm{Al}_{3} \mathrm{Mg}_{3} \mathrm{SiFe}$ \\
& $\mathrm{Al}_{7} \mathrm{Cu}_{3} \mathrm{Mg}_{6}$ \\
\hline
\end{tabular}

In the modified alloys B95 and B96 (Fig. 3).

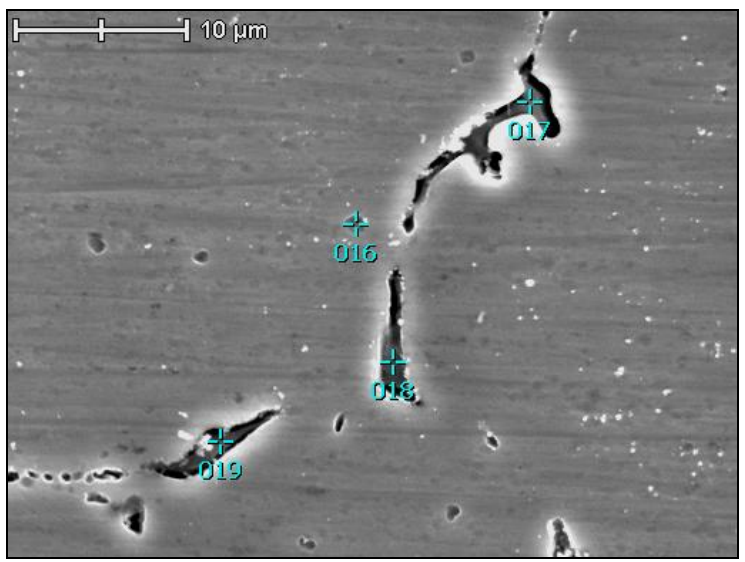

Figure 3. Microstructure of 01570 alloy with intermetallic phases

$\mathrm{Al}_{3} \mathrm{Mg}_{3} \mathrm{SiFe}$ and $\mathrm{Al}_{7} \mathrm{Cu}_{3} \mathrm{Mg}_{6}$ intermetallic phases of a complex composition were also found, which are uncharacteristic for the alloy in the initial state, $\quad \mathrm{Mg}_{32}(\mathrm{AlCu})_{49}, \quad \mathrm{Al}_{7} \mathrm{Cu}_{3} \mathrm{Mg}_{6}$, $\mathrm{Al}_{3} \mathrm{Mg}_{3} \mathrm{SiFe}$ (Table 3).

The appearance of new complex intermetallic compounds, as well as titanium diborides and aluminides, indicates the effective influence of the modifier on the crystallization of alloys.

The microstructure of the B95 alloy in its initial state (Fig. 2.a) consists of $\alpha$-Al, a solid solution in the presence of massive boundaries of intergrowth between the branches of dendrites.

In the modified alloy samples (Fig. 2.b), thin intergrowths of dendrites and their branches are observed, as well as localized inclusions inside dendrites. A stable alloy structure was achieved, which is associated with a more uniform distribution of alloying elements included in the alloy under the action of a nanodispersed modifier. Modified samples are characterized by a smaller grain size (70 microns) compared to the original ones (200 microns). 
The study of the distribution of alloying elements and impurities in the aluminum base of the alloy before and after modification (Table 3) showed a more uniform distribution of aluminum, zinc, iron and silicon. A decrease in the content of magnesium and copper indicated their presence in the intermetallic phases. The increased content of titanium (from 0.12 to $0.44 \%$ ) proves its involvement in the modification process.

Table 3 - Results of X-ray microspectral analysis of intermetallic phases of alloy B95

\begin{tabular}{|c|c|c|c|c|c|c|c|}
\hline $\begin{array}{c}\text { Sample } \\
\text { Condition }\end{array}$ & \multicolumn{5}{|c|}{ The content of alloying elements, \% } \\
\cline { 2 - 8 } & $\mathrm{Al}$ & $\mathrm{Zn}$ & $\mathrm{Fe}$ & $\mathrm{Mg}$ & $\mathrm{Cu}$ & $\mathrm{Si}$ & $\mathrm{Ti}$ \\
\hline Unmodified & 84,13 & 2,48 & 6,58 & 2,12 & 2,84 & 1,83 & 0,02 \\
\hline $\begin{array}{c}\text { Modified } \\
0,01 \% \\
\text { Ti+0,005\%B }\end{array}$ & 84,86 & 1,73 & 4,19 & 2,14 & 2,23 & 4,73 & 0,12 \\
\hline $\begin{array}{c}\text { Modified } \\
0,05 \% \\
\text { Ti+0,005\%B }\end{array}$ & 81,9 & 2,0 & 4,50 & 2,16 & 2,70 & 6,30 & 0,44 \\
\hline
\end{tabular}

Table 4 shows the mechanical properties of B95 alloy after hardening heat treatment.

From the above data it follows that $(0.05 \%$ $\mathrm{Ti}+0.005 \%$ B) modifying composition is the most effective, as a result of which grain refinement from 200 to 70 microns, an increase in the strength properties of alloys from 240 to 400 $\mathrm{MPa}$ and an increase in microhardness to 1500 MPa were achieved.

Table 4 - Mechanical properties of alloy B95 before and after modification

\begin{tabular}{|c|c|c|c|c|c|c|c|}
\hline \multicolumn{2}{|c|}{ Modifier, wt \% } & \multirow[b]{2}{*}{$\begin{array}{c}\sigma \mathrm{B}, \\
\text { МПа }\end{array}$} & \multirow[b]{2}{*}{$\begin{array}{l}\sigma_{0.2} \\
\mathrm{MPa}\end{array}$} & \multirow[b]{2}{*}{$\delta, \%$} & \multirow{2}{*}{ 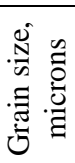 } & \multirow[b]{2}{*}{$\begin{array}{c}\mathrm{KCU} \\
\mathrm{MJ} / \mathrm{m}^{2}\end{array}$} & \multirow[b]{2}{*}{$\begin{array}{l}\mathrm{H} \mu, \\
\mathrm{MPa}\end{array}$} \\
\hline $\mathrm{Ti}$ & B & & & & & & \\
\hline- & - & 240 & 202 & 8,0 & 200 & 0,36 & 1080 \\
\hline 0,01 & - & 250 & 214 & 7,1 & 185 & 0,30 & 1120 \\
\hline 0,05 & 0,005 & 400 & 360 & 5,6 & 70 & 0,25 & 1500 \\
\hline 0,07 & 0,005 & 320 & 280 & 4,8 & 160 & 0,28 & 1455 \\
\hline 0,1 & 0,005 & 350 & 308 & 4,6 & 100 & 0,30 & 1460 \\
\hline
\end{tabular}

\section{Conclusion}

1. The criteria for the modification of highstrength multicomponent aluminum alloys are determined.

2. The choice of a composition of nanodispersed powders of titanium and boron of a fraction up to $100 \mathrm{~nm}$ obtained by plasmachemical synthesis as a complex modifier of aluminum alloys is justified.

3. Using the method of X-ray diffraction analysis and X-ray spectral analysis in modified alloys, a large number of intermetallic phases of complex composition were found that are absent in the initial alloys, which ensures a hardening effect.

4. The $(0.05 \% \mathrm{Ti}+0.005 \% \mathrm{~B})$ modifying composition is most effective, as a result of which grain refinement from 200 to 70 microns, an increase in the strength properties of alloys from 240 to $400 \mathrm{MPa}$ and an increase in microhardness to $1500 \mathrm{MPa}$ were achieved.

\section{Литература}

1. Мальцев М.В. Модифицирование структуры металлов и сплавов. Москва: Металлургия, 1970. 282 с.

2. Модифицирование сталей и сплавов дисперсными инокуляторами. В.П. Сабуров, Е.Н. Еремин, А.Н. Черепанов, Г.Н. Миннеханов. Омск: ОмГТУ, 2002. 257 с.

3. Марухович Е.И., Стеценко В.Ю. Модифицирование сплавов. Минск: Беларуская наука, 2009. $192 \mathrm{c}$.

4. Ferguson I.B. Cerrelation vs Causatioln: The Effects of Ultrasonic Melt Theatment on cast Metal Grain Size. Metals. 2014. № 4. p. 477-486.

5. Sinh A.K. On the formation of disordered solid solutions in multicomponent alloys. Jurnal of Alloys and Compounds. 2014. Vol. 587. p. 113119.

6. Baloyan B.M., Kolmakov A.G., Alymov M.I., Moles A.M. Nanomaterials, Ugrina, Moscow (2007) (Russian).

7. Kalinina N.E., Nikiforchin G.M., Kalinin O.V. at al., Structure, Properties and Use: structures, of Materials, Prostir-M, Lviv (2017). p. 304.

8. Костин В.А., Григоренко Г.М., Жуков В.В. Модифицирование структуры сварных швов высокопрочных сталей наночастицами тугоплавких металлов // Строительство, материаловедение, машиностроение. Днепр: ПГАСА, 2016. Вып. 89. С. 93-98.

9. Березовская В.В., Ишина Е.А., Озерец Н.Н. Диаграммы состояния тройных систем: учебное пособие. Екатеринбург: УрФУ, 2016. $119 \mathrm{c}$.

10. Kalinina N.E., Glushkova D.B., Voronkov A.I., Kalinin V.T. Influence of nano modification on structure formation of multicomponent Nialloys // Function Materials, 26, 3 (2019). 514-518 p.

11. Диаграммы двойных металлических систем: справочник в 3-х т. / под ред. Н.П. Лякишева. Москва: Машиностроение, 1999. Т. 3. 880 с. 


\section{References}

1. Maltsev M.V. Modification of the structure of metals and alloys. Metallurgy, Moscow (1970). p. 282 [in Russian].

2. Saburov V.P., Eremin E.N., Cherepanov A.N., Minnekhanov G.N. Modification of steels and alloys with dispersed inoculators, OmSTU, Omsk (2002), p. 257 [in Russian].

3. Marukhovich E.I., Stetsenko V.Yu. Alloy Modification, Belarusian science, Minsk (2009), p. 192 [in Belarus].

4. Ferguson I.B. Cerrelation vs Causatioln. The Effects of Ultrasonic Melt Theatment on cast Metal Grain Size, Metals, 4, (2014), p. 477-486 [in USA].

5. Sinh A.K. On the formation of disordered solid solutions in multicomponent alloys, Jurnal of Alloys and Compounds, (2014), p. 113-119 [in India].

6. Baloyan B.M., Kolmakov A.G., Alymov M.I., Moles A.M. Nanomaterials, Ugrina, Moscow (2007) [in Russian].

7. Kalinina N.E., Nikiforchin G.M., Kalinin O.V. at al., Structure, Properties and Use structures of NanoMaterials Prostir-M, Lviv (2017). p. 304 [in Ukraine].

8. Kostin V.A. Modification of the structure of welds of high strength steels by nanoparticles of refractory metals, Construction, materials science, mechanical engineering, Dnipro, 89, (2016), p. 93-98 [in Russian].

9. Berezovskaya V.V., Ishina E.A., Ozerets N.N. State diagrams of ternary systems. Tutorial Yekaterinburg: UrFU, (2016) p. 119 [in Russian].

10. Kalinina N.E., Glushkova D.B., Voronkov A.I., Kalinin V.T. Influence of nano modification on structure formation of multicomponent Nialloys. Function Materials, 26, 3 (2019). p. 514-518 [in Ukraine].

11. Lyakisheva N.P. Double metal system diagrams. Directory, 3, Moscow (1999), p. 880 [in Russian].

Kalinina N. Doct. Sc., Department of Production Technology, tel.: 095-550-28-00, O. Honchar Dnipro National University, 72 Gagarina Ave., 49010 Dnipro, Ukraine: kalinina.dnu @ gmail.com

Kalinin A., PhD student, Department of Materials Science and Materials Processing,

vt.kalinin@gmail.com

State Higher Educational Institution Prydniprovska State Academy of Civil Engineering and Architecture, 24a Chernishevsky St., 49600, Dnipro, Ukraine. Hlushkova D., Doct. Sc., Chef of Department of Technology of Metals and Materials Science, tel.: 057-707-37-29,diana@khadi.kharkov.ua,

Voronkov A., Doct. Sc., Professor, Department of Internal Combustion Engines, tel.: 057-707-37-29, dralexadi@gmail.com,

Stepaniuk Anrey. - Assistant, Department of Metal Technology and Materials Science, tel.: +38 097-525-85-13, dioxid26@meta.ua
Kharkiv National Automobile and Highway University, 25, Yaroslava Mudrogo str., Kharkiv, 61002, Ukraine,dralexadi@gmail.com

Voronova E., associate professor, $\mathrm{PhD}$, Department of Foreign Languages, voronova1945@gmail.com, Kharkiv National Automobile and Highway University, 25, Yaroslava Mudrogo str., Kharkiv, 61002, Ukraine.

Serzhenko I., graduate student, Department foundry, lady.Anna.We@gmail.com

National Metallurgical Academy of Ukraine, Dnipro, Ukraine.

Вплив обробки нанодисперсними композиціями на структуроутворення високоміцних алюмінісвих сплавів.

Анотація. Проведено аналітичний огляд стану проблеми модифікування алюмінієвих сплавів. Встановлена відсутність єдиного підходу до вирішення цієї проблеми, що пов'язано зі складністю прочесу модифікування багатокомпонентних сплавів. Досліджували алюмінієві сплави системи AL-Zn-Mg-Cu. Модифікатором запропонована композиція на основі нанодисперсних порошків титану $i$ бору фракиії до 100 нм, які були отримані плазмохімічним синтезом. Вивчали структуру, фазовий склад $i$ властивості зразків, які досліджувались до $i$ після модифікування методами оптичноі мікроскопї, рентгеноструктурного $i$ мікрорентгеноструктурного аналізу. Умодифікованих сплавах В95 $і$ В96 досягнуто подрібнення зерна $і$ стабілізачія структури. Визначення параметрів кристалічної решітки сплавів показало збільшення періоду решітки модифікованих зразків на 1,02\%. Підвищена мікротвердість $\alpha-A l$ - твердого розчину з 1080 до 1500 МПа. Фазовий склад сплавів В95, В96 представлений інтерметалідними фазами $\mathrm{CuAl}$, $\mathrm{MgZn}_{3}, \mathrm{Mg}_{2} \mathrm{Zn}_{3}, \mathrm{Mg}_{2} \mathrm{Si}, \mathrm{FeAl}_{3}, \mathrm{TiB}_{2}, \mathrm{TiAl}_{3}$, а також фазами складного стану. Максимальне здрібнення зерна $i$ підвищення механічних властивостей сплавів досягнуто за умови модифікування: $0,05 \%$ Ti ma 0,005\% пояснюється утворенням дисперсних змічнювальних інтерметалідних фаз складного стану в центрі зерна.

Ключові слова: алюмінієві сплави, структура, фазовий склад, інтерметалічні фази, наномодифікатор, титан, бор.

Калініна Наталія Свграфівна, д.т.н., професор кафедри технології матеріалів, 095-550-28-00, kalinina.dnu@gmail.com

Дніпровський національний університет імені Олеся Гончара, пр. Гагаріна, 72,

м. Дніпро, Україна. kalinina.dnu@gmail.com

Калінін Олександр Васильович, докторант кафедри матеріалознавства та обробки металів Придніпровської державної академії будівництва та архітектури, вул. Чернишевського 24а, Дніпро, 49600, Україна, vt.kalinin@gmail.comм. . 
Глушкова Діана Борисівна, д.т.н., проф., завідувач кафедри технології металів та матеріалознавства, diana@khadi.kharkov.ua, 057-707 37-29, diana.borisovna@gmail.com,

Воронков Олександр Іванович, д.т.н., професор кафедри двигунів внутрішнього згоряння, 067-295-90-96, dralex@gmail.com,

Степанюк Андрій Іванович, асистент кафедри технології металів та матеріалознавства,

097-525-85-13,dioxid26@meta.ua

Воронова Слизавета Михайлівна, доцент кафедри іноземних мов, voronova1945@gmail.com,

Харківський національний автомобільнодорожній університет, вул. Ярослава Мудрого 25, м. Харків, 61002, Україна.

Серженко Іванна Олегівна, аспірант кафедри ливарного виробництва,

lady.Anna.We@gmail.com

Національна металургійна академія України, Дніпро, Україна.

\section{Влияние обработки нанодисперсными композициями на структурообразование высоко-прочных алюминиевых сплавов}

Аннотация. Проведён аналитический обзор состояния проблемы модифицирования алюминиевых сплавов. Установлено отсутствие единого подхода решения проблемы, что связано со сложностью прочесса модифииирования многокомпонентных сплавов. Исследовали алюминиевые сплавы системы AL-Zn-Mg-Cu. В качестве модификатора предложена композищия на основе нанодисперсных порошков титана и бора фракиии до 100 нм, полученные плазмохимическим синтезом. Исследовали структуру, фазовый состав и свойства опытных образиов до и после модифицирования методами оптической микроскопии, рентгеноструктурного и микрорентгеноспектрального анализа. В модифицированных сплавах В95 и В96 достигнуто измельчения зерна и стабилизачия структуры. Определение параметров кристаллической решетки сплавов показало увеличение периода решетки модифицированных образиов на 1,02\%. Повышена микротвёрдость $\alpha-A l-$ твёрдого раствора с 1080 до 1500 МПа. Фазовый состав сплавов В95, В96 представлен интерметаллидными фазами $\mathrm{CuAl}_{2}$, $\mathrm{MgZn}_{3}, \mathrm{Mg}_{2} \mathrm{Zn}_{3}, \mathrm{Mg}_{2} \mathrm{Si}, \mathrm{FeAl}_{3}, \mathrm{TiB}_{2}, \mathrm{TiAl}_{3}$, а также фазами сложного состава. Максимальное измельчение зерна и повышение механических свойств сплавов достигнуто при модифицировании: 0,05\% Ti и 0,005\% В, что объясняется образованием дисперсных упрочняющих интерметаллидных фаз сложного состава в центре зёрен.

Ключевые слова: алюминиевые сплавы, структура, фазовый состав, интерметаллические фазы, наномодификатор, титан, бор.

Калинина Наталия Евграфовна, д.т.н., профессор кафедры технологии материалов, 095-550-28-00. kalinina.dnu@gmail.com

Днепровский национальный университет имени Олеся Гончара, пр. Гагарина, 72,

г. Днепр, Украина.

Калинин Александр Васильевич, докторант кафедры материаловедения и обробки металлов Приднепровской государственной академии строительства и архитектуры, ул. Чернышевского 24a, г. Днепр, 49600, Украина.

vt.kalinin@gmail.com

Глушкова Диана Борисовна, д.т.н., проф., заведующая кафедрой технологии металлов и матераловедения, 057-707 37-29,

diana.borisovna@gmail.com,

Воронков Александр Иванович, д.т.н., профессор кафедры двигателей внутреннего згорания, 067-295-90-96, dralex@ gmail.com,

Степанюк Андрей Иванович, ассистент кафедры технологии металлов и материаловедения, 097-525-85-13, dioxid26@meta.ua

Воронова Елизавета Михайловна, доцент кафедры иностранных языков, voronova1945@gmail.com,

Харьковский национальный автомобильнодорожный университет, ул. Ярослава Мудрого 25, м. Харків, 61002, Украина.

Серженко Иванна Олеговна, аспирант кафедры литейного производства,

lady.Anna.We@gmail.com

Национальная металлургическая академия Украины, Днепр, Украина. 